\title{
Competitive Advantage in the Magazine Publishing Business
}

\author{
A Resource-Based Perspective
}

\author{
Helene Hafstrand
}

When studying the magazine publishing business in the Nordic countries, two trends are particularly apparent. The first trend is the decline of the general interest magazines and, on the other hand, the expansion of the special interest and the lifestyle magazines. The second trend is that the international markets are becoming increasingly important. Magazine publishing, at least when talking about the bigger publishing companies, is increasingly an international business. For the Nordic publishers this trend means a possibility of expansion in new markets, but it also means the threat of new competitors in the home market. The magazine publishing industry also has to deal with the rapid development of the Internet, which can be considered both a threat and a possibility. In order to survive and prosper in a changing industry structure and competitive situation, a magazine publishing company clearly more than ever requires a viable competitive strategy.

In this article, possible sources of sustainable competitive advantage for magazine publishing companies are discussed from a resource-based perspective. After a short summary of the basic theoretical concepts of the resource-based view of the firm, follows a discussion of the shortcomings of the value chain framework for decomposing the value creation logic of a magazine publishing company and an alternative model, the value network, is suggested. Based on the latter model some examples of possible sources of competitive advantage in the magazine business are given.

\section{The Resource-Based View}

During the late 1970s and early 1980s, the strategy literature emphasized the external environment of the firm. The focus was on the analysis of the industry attractiveness and the competition. The work of Harvard economist Michael Porter was very influential. But in the late 1980s and early 1990s, the focus increasingly shifted towards the internal aspects of the firm. According to the so-called resource-based view of the firm, competitive advantage is seen as being dependent less upon a firm's chosen position within an industry and more upon the exploitation of unique internal resources and capabilities.

As the resource-based view of the firm to some extent evolved as a reaction to the dominance of the external perspective on strategy, some authors proclaim that it is a new and alternative theory of strategy. Others argue that there are important advantages to be 
gained by linking and integrating the two views. The view that strategy is about linking the opportunities and threats in the external environment with the internal strengths and weaknesses of the company goes back to the seminal work of Andrews in the 1970s.

The resource-based view of the firm has its roots in the writings of the well-known economists David Ricardo, Joseph Schumpeter and Edith Penrose (Grant, 1991). However, the growing interest and the mass of publications over the past years have caused considerable terminological confusion. Competence, core competence, visible and invisible assets, strategic assets, strategic stocks, resources, skills etc. are used to refer to strategic components of one type or another (Bogaert et al., 1994).

Barney (1991) has a broad definition of firm resources - they include all assets, capabilities, organizational processes, firm attributes, information, knowledge etc., controlled by a firm and enabling it to conceive of and implement strategies that improve its efficiency and effectiveness. A firm's resources thus include, according to Barney, both tangible and intangible resources and he makes no clear distinction between what a firm does and what it has. Wernerfelt (1984) has a similar, broad definition. A firm's resources are those tangible and intangible assets that are tied semipermanently to the firm. Examples given by Wernerfelt are brand names, in-house knowledge of technology, employment of skilled personnel, trade contracts, machinery, efficient procedures and capital.

Strategic assets are those that underpin the competitive advantage of the firm. Strategic assets have four attributes: they are valuable, they are rare among the firm's current and potential competitors, they are imperfectly imitable and no strategically equivalent substitutes exist (see, e.g., Dierickx and Cool 1989, Barney 1991, 1994, Bogaert et al., 1994, Habann, 2000).

Dierickx and Cool (1989) distinguish between asset stocks and flows. Firms deploy both tradable and nontradable assets. When an asset is nontradable on the factor market, the firm has to deploy it in product markets in order to tap its rent earning potential. Conversely, a firm that does not own a nontradable asset, which it needs to implement its product market strategy, has to build this asset. For example, a reputation for quality may be built by following a consistent set of policies regarding production, quality control etc. Strategic asset stocks are accumulated by choosing appropriate time paths of flows over a period of time.

Dierickx and Cool use the "bath-tub metaphor" to illustrate the difference between stocks and flows: "At any moment in time, the stock of water is indicated by the level of water in the tub; it is the cumulative result of flows of water into the tub (through the tap) and out of it (through a leak). In the example of R\&D, the amount of water in the tub represents the stock of know-how at a particular moment in time, whereas current $\mathrm{R} \& \mathrm{D}$ spending is represented by the water flowing in through the tap; the fact that knowledge depreciates over time is represented by the flow of water leaking through a hole in the tub. A crucial point illustrated by the bathtub metaphor is that while flows can be adjusted instantaneously, stocks cannot. It takes a consistent pattern of resource flows to accumulate a desired change in strategic asset stocks" (p.1506). Critical or strategic asset stocks are those assets that are nontradable, nonimitable and nonsubstitutable.

A frequent distinction made in the literature is between having, i.e. what the firm owns that is superior to the competitors, and doing, i.e. what the firm or parts of it does better than competitors (see, e.g., Aaker, 1989, Hall 1994). Assets or resources are notions used to refer to what a firm owns, and skills, competencies or capabilities refer to what a firm does. Assets can be both tangible and intangible. Examples of intangible assets are intellectual property rights such as patents, trademarks, copyright and registered design or brand reputation (Bogaert et al., 1994). 
Other authors, such as Grant (1991), make distinctions between resources and capabilities. Resources, according to Grant, are inputs into the production process. These could be financial resources, physical resources, human resources, technological resources, reputation and organizational resources. But resources are not productive in themselves. A capability, according to Grant, is the capacity for a team of resources to perform some task or activity. Thus, resources are the source of a firms capabilities and these in turn the main source of its competitive advantage.

Amit and Schoemaker (1993) make a similar distinction when they define resources as "stocks of available factors that are owned or controlled by the firm. Resources are converted into final products or services by using a wide range of other firm assets and bonding mechanisms such as technology, management information systems, incentive systems, trust between labor, and more" (p. 35). Capability, according to Amit and Schoemaker, refers to the capacity of a firm to deploy resources using organizational processes to effect a desired end. Capabilities are "information-based, tangible or intangible processes that are firm-specific and are developed over time through complex interactions among the firm's resources" (p. 35). Thus, competitive advantage can evolve from distinctive competencies, which are the capabilities the organization possesses that set it apart from its competitors. The firm should identify its key business processes, manage them centrally and invest in them (Bogaert et al., 1994).

A concept closely related to the resource-based view is that of core competencies, introduced by Hamel and Prahalad. Core competencies arise through the collective learning of the firm, especially through coordinating diverse production skills and integrating multiple streams of technologies (Rumelt,1994). Core competencies are enhanced through use and they span across several businesses and products within a corporation. Hamel and Prahalad (1990) suggest that management should develop a corporate-wide strategic architecture, "a road map of the future that identifies which core competencies to build and their constituent technologies" (p. 89).

\section{Asset Accumulation}

Strategic assets are accumulated over time. If the processes by which the assets are accumulated represent barriers to replication for competing firms, a business that can increase the speed and reduce the cost of asset accumulation will be in a position to generate competitive advantage (Verdin and Williamson, 1984).

Dierickx and Cool (1989) offer an often cited analysis of when it can be time consuming, costly or both for competitors to replicate a non-tradable asset stock possessed by a firm. Imitability depends on the characteristics of the process by which the asset stock is accumulated.

Time compression diseconomics. The "law of diminishing returns" when one input, viz. time, is held constant. "Crash" R\&D programs are typically less effective than programs where annual R\&D outlays are lower but spread out over a proportionally longer period of time.

Asset mass efficiencies. Some types of assets are less costly to accumulate when the firm already possesses high levels of that asset stock. Historical success translates into favorable initial asset stock positions, which in turn facilitate further asset accumulation. Catching up from low initial levels may be difficult, especially when critical mass is required. This might be the case, for example, when the value of a product or service depends on the number of "members" in the network, as for instance in the credit card business. 
Interconnectedness of asset stocks. The accumulation process of an asset stock can also be dependent on the level of other asset stocks. For example, it may be harder for a firm that lacks a service network to improve its product quality since it does not have access to in-house information from the field.

Asset erosion. Just as for physical plants and equipment, all asset stocks need to be maintained, or they will erode. If a firm, for example, does not continuously invest in its brand, brand loyalty will eventually erode as new consumers enter the market, as consumers forget etc. Advertising expenditure is a flow variable while brand awareness is a stock variable. According to Dierickx and Cool, flow variables are not in general credible vehicles for entry deterrence, whereas brand loyalty is.

Causal ambiguity. The accumulation of asset stocks is not always a deterministic and continuous process. In many industries it is better described as stochastic and discontinuous. Dierickx and Cool describe what they call a "jackpot model": "Firms sink R\&D flows in projects with highly uncertain outcomes, and only few firms actually "hit the jackpot" by bringing out highly successful products. The stocks vs. flows framework ... can easily be accommodated to deal with such industries. In fact, the levels of the firm's stocks will determine each firm's probability of success, i.e. different firms try their fortunes on different slot machines, the odds of each machine being set by the levels of that firm's relevant asset stocks" (pp. 1508-1509). When uncertainty is high as to the role different factors play in the accumulation process, it is almost impossible for other firms to imitate that asset stock.

\section{Value Chain vs. Value Network}

The value chain framework (Porter, 1985) is a method for decomposing the firm's value creation logic into discrete activities in order to understand their impact on the relative cost position and their ability to create a basis for differentiation. The value creation of a firm is depicted as a chain of sequentially interlinked primary activities that gradually transform raw materials into finished products. The five primary activity categories are inbound logistics, operations, outbound logistics, marketing and sales and service. Five categories of support activities are linked to the primary activities. These support activities are procurement, technology development, human resource management and firm infrastructure.

The activities associated with the very production of the physical magazine can readily be described and decomposed in accordance with the value chain framework. Very briefly, inbound logistics is the editorial content, i.e. texts, articles, pictures etc. organized according to a specific lay-out, operations is the printing process and outbound logistics the distribution to the sales outlets. Marketing and sales are directed to consumers, advertisers, distribution channels as well as intermediaries. But for different reasons, the value chain framework is incapable of capturing the core value creation logic of a magazine publisher.

A strong trend within the magazine business during the past decades is decreasing vertical integration. Many magazine publishers have divested their printing facilities and instead purchased printing capacity on the open market. An exception is publishers with printing facilities dimensioned for very high volumes, i.e. some of the German magazine publishers. Due to the capacity they can also compete for other high volume jobs on an open market. Another notable exception is the Swedish branch of the Aller company. The distribution function on the Swedish market is carried out by organizationally independ- 
ent companies, Tidsam and to some extent Interpress. Tidsam is owned and controlled by the larger magazine publishers, which can be a major entry barrier as well as a strategic asset. On the other hand, the Swedish Competition Authority has urged the owners of Tidsam to open up the system for titles from competing publishers. Also the subscription routines are handled by independent companies. Thus, the value chain briefly described above captures the activities and the different companies associated with the physical production and distribution of a magazine, but it could be argued that it does not capture the core value creation logic of a single magazine publisher.

Magazine publishing is largely a creative business with several similarities to the service industry. The value chain framework is often criticized for not being able to capture the value creation logic of these kinds of companies. For a magazine publisher, the core value creating activities have taken place before or simultaneously with the physical production of the magazine and cannot be described as a sequential process. Thus a different framework seems to be needed to facilitate our understanding of the activities, resources deployed, capabilities and thus the potential for sustainable competitive advantage for a magazine publisher.

Building on Thompson's (1967) typology of long-linked, intensive and mediating technologies, Stabell and Fjeldstad (1998) suggest three different value configuration models. The long-linked technology delivers value by transforming inputs into products. The value creating logic of the long-linked technology is thus captured by the value chain framework. The intensive technology, or the value shop as Stabell and Fjeldstad call it, delivers value by resolving unique customer problems. Hospitals, professional service firms and educational institutions are common examples of firms that rely on an intensive technology.

The mediating technology, or the value network, delivers value by facilitating a network relationship between their customers. The firm itself is not the network; it provides a networking service. Examples given of companies that create value by facilitating exchange among their customers are telephone companies, transportation companies, insurance companies and banks. Although the value network metaphor is not completely applicable to a magazine publishing company, it offers a different angle of approach to how the value creating activities can be described and analyzed.

A common view is that the core value creating activities of a magazine publishing company are tied to the production of content. Knowledge about the needs and preferences of the potential readers and a distinctive competence in producing the kind of content that satisfies these needs and preferences are seen as the key to success, often expressed in circulation numbers. High circulation, or merely high reach in well-defined target groups, is regarded as the main competitive factor on the advertising market. If the core competence and main strategic assets of a magazine publisher are the production and ownership through copyright of content, a viable competitive strategy would be to deploy these assets and competencies in other technologies, such as on the Internet or in television programs.

If instead a magazine publishing company is pictured as a value network, the publishing company becomes a conductor in a network that interconnects readers, advertisers and the different actors on what can be called a "content market". The paper-based issue of the magazine is the mediating technology, but value is created not primarily in the production of the physical magazine but in the organization and facilitation of exchange between readers, advertisers and the different actors on the content market (Figure 1). 
Figure 1. The Magazine Publishing Company as a Value Network

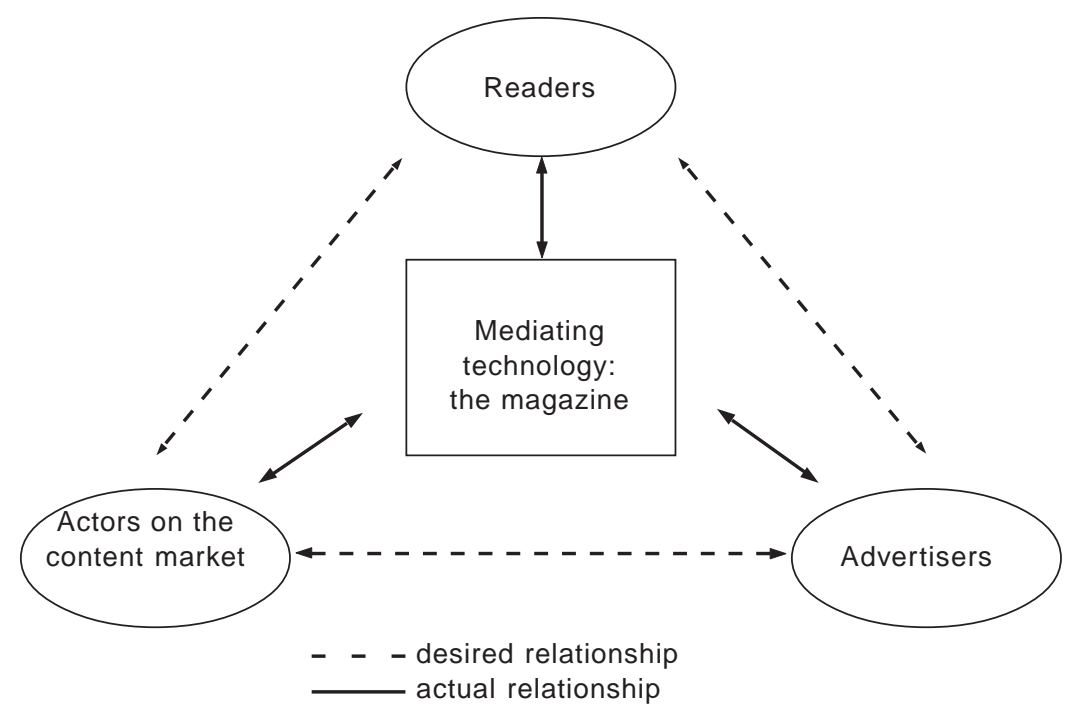

It is obvious that there is an exchange between readers and advertisers. Advertisers use the magazine to communicate with the readers. Very often, though not always, the readers also wish to be connected with the advertisers. This is especially true for special interest magazines, where the advertisements can play a more informative role than is the case in general interest magazines. But also in the case of, for instance, a fashion magazine, the advertisements can be of value to the readers.

It is also possible to regard the magazine as a mediating technology for linking readers and the actors on a content market. This market consists of people, i.e. artists, celebrities, royalties etc., companies, organizations and other groupings who need or desire media attention for different reasons, be it to spread a message or an idea or simply to gain legitimacy. Journalists, then, can be considered as intermediaries between the content market and the readers. Needless to say, this does not imply that the journalists simply pass on messages from the content market. They create content based on what they perceive is happening on the content market, a place for exchange of influences, ideas, information etc.

Even if a magazine publishing company is pictured as a value network, the content, and how it is presented in the physical magazine, is still the most important outcome. But it could be argued that the content as such is not the potential basis for competitive advantage. Content can be traded and imitated. This is obvious if you compare the topics chosen and the articles in different magazines. It is even more obvious if you compare some Swedish magazines with their international role models. Instead, it is merely the core competencies or the capabilities to organize and manage the network that can generate a sustainable competitive advantage. As a consequence, diversification should be based on these capabilities and to a less degree on content. Instead of considering an Internet site as a new channel or technology for distributing content, the networking capabilities could be used to enable an interactive communication between the readers/ surfers, the actors on the content market and the advertisers, i.e. to organize a Virtual 
Community. In an analysis of the web sites of Scandinavian, German, British and American magazine publishers (Brodin and Ekdahl, 2000), the authors concluded that IPC, Hearst Corporation and Rodale Press act as organizers of Virtual Communities and that several other publishers are developing their web sites in the same direction.

\section{The Value Network as a Club}

According to Stabell and Fjeldstad (1998), managing a mediating firm in a value network can be compared to managing a club. The mediating firm admits members that complement each other and in some cases excludes those that do not. An important task for a publishing company thus is to decide who will be a part of the network and who will not. This is done both on the level of the single title, in possible joint functions such as advertising sales, and on the business unit and corporate level through strategic management. The suitable "members" of the network are a result of the interdependence between the editorial content of the single title, it's readership profile and the advertising market. There has to be a fit between the actors from the content market that are let in, e.g. the editorial profile, the demographic and lifestyle profile of the readers, and the kind of advertisers.

The advertisers are also a part of the editorial environment; they contribute to the "soul" of the magazine. This means that not only the amount of advertisers is of importance for the survival of a magazine, but also selection of the "right" advertisers. For instance, one contributing factor to the lack of success for magazines targeted at the commercially interesting 50+-segment on the Swedish market is said to be the problem of attracting the "right" advertisers, i.e. travel organizers, insurance companies, producers of capital goods etc. Instead the magazines were dominated by advertisements about health care products and prescription-free drugs for elderly people, which ruined the editorial environment.

\section{Strategic Resources and Capabilities in the Magazine Business}

As stated in the literature review, strategic assets or resources are those that are nontradable, nonimitable and nonsubstitutable. Some authors, i.e. Grant (1991), make a clear distinction between what a firm has - resources and assets - and does - capabilities, skills, competencies - and argue that it is what a firm does, i.e. its capabilities to manage the resources, that is the main source of competitive advantage. In a value network perspective, these capabilities are to be found in how the different magazine publishing companies manage the network. In the following, possible sources of competitive advantage are discussed within three different areas - human resource management, market knowledge and product development.

\section{Human Resource Management}

The heart of a magazine is the editorial staff, especially the editor. Typically, an editor is given considerable freedom to put his or her personal "touch" on a magazine. Creating a magazine is sometimes considered an art and the editor is the artist, who needs his or her creative freedom. In the magazine business, as in many other media companies, there is a considerable element of the "guru-factor".

But having talented editors employed cannot be a sustainable competitive advantage according to the resource-based view, since editors are "tradable", i.e. they can easily 
move on to another magazine. Instead, the potential for a sustainable competitive advantage is the capabilities within human resource management, for instance to find, employ, educate, stimulate and tap the full potential of gifted editors. Here the larger publishers have a clear advantage. They have the financial capacity to pay the salary needed. They can educate journalists and offer them a career path by letting them work on different magazines and also in different business units. For instance in the Bonnier group, the largest media group in Sweden, several editors have also worked on the evening tabloids. Talented editors can also be used as a "fire brigade". For instance, the almost legendary Gunny Widell has many times, during her long career within the Bonnier group, successfully turned around a magazine in crisis.

Company reputation is also a valuable resource with regard to attracting employees. In spring 2001, four journalists left the male lifestyle magazine Slitz for the competitor Café. The timing might seem odd - after several years of keen competition, Slitz is the market leader within the segment while the future for Café is very unsure. But the move can be explained by the fact that Café has a better reputation and that it is owned by the multinational publisher Hachette, while Slitz is the single title published by an entrepreneur who does not have the best reputation in the business.

\section{Market Knowledge}

A magazine publisher competes on three markets - the advertising, the circulation and the content market. Again according to the resource-based view, it is not specific knowledge at a certain time that can generate a sustainable competitive advantage. Specific knowledge can be bought on the open market through market research. It is the information systems, the accumulated knowledge in the organization and the capability to react to signals from the market that are nontradable and hard to imitate. Market research is what Dierickx and Cool call a flow variable, the water flowing into the bathtub through the tap, while market knowledge is a stock variable, the water accumulated in the bathtub during a long time, which cannot be adjusted instantaneously.

A good example of this is the German publisher Gruner + Jahr and their entry on the British market in the late 1980's. The two titles Prima and Best were originally developed by the French subsidiary Prisma Presse. A two-year-long research and development program was followed by a test launch in the south of France. After that, launches were made in France, Spain and Germany. When Gruner + Jahr entered the British market the extensive research program carried out in France had become a stock variable that could also be used on the British market, and therefore the launching decisions for Prima and Best could be made rather quickly.

An important source for market information is the sales force. A publisher that chooses to outsource the advertising sales function to an independent company, which is often the case with smaller publishers, does not have access to the information picked up by the sales force. The interrupted launch in autumn 1999 of the Bonnier male lifestyle magazine Adam illustrates the importance of information from the advertising market. The magazine was scheduled to hit the shelves in September. During the spring and summer, a dummy was presented to the potential advertisers. Shortly afterwards, Bonniers decided not to launch the magazine. It is reasonable to believe that it was the contact with and reactions from the advertisers that made them change their minds. 


\section{Product Development}

In a sense, a magazine publishing company delivers a new product every week or every month. Product development is a continuing process. Reiner and Gosh (1988) from Boston Consulting Group claim that other companies have a great deal to learn from the way magazine publishers handle product development. Companies need to invest actively in the activities that support rapid product development. According to Reiner and Gosh, directing this investment is a key function of senior management. An important source of competitive advantage for a magazine publishing company is thus the capabilities and competencies to coordinate human, technical and organizational resources in a way that enhances continuing product development.

There is a close and mutual relationship between market knowledge and product development. But there is also considerable causal ambiguity involved. A thorough market research and development job is no guarantee that the launch of a new title will succeed. The news magazine title Reportage, launched by Bonniers 1980, is a good example of this. The results from market research and testing indicated a major success, but the title turned out to be a complete failure and was withdrawn only a few month after the launch. On the other hand, when Bonniers thirty years ago launched the first food magazine on the Swedish market, Allt om Mat, several people in the business were skeptical to the concept. But Allt om Mat turned out to be a success and is still the leading food magazine despite several competing titles. The "jackpot model" by Dierickx and Cool seems to be very relevant in the magazine publishing business - launching new titles is like playing on a slot machine, but the odds of each machine is set by the level of the company's relevant asset stocks.

A special case of new product development is when a publisher uses a concept as leverage for international expansion, as for instance is the case of the fashion magazine Elle, owned by the French publisher Hachette. Each national edition is largely adapted to the specific market and is often launched in cooperation with a leading national publisher. The concept as such could probably both easily and legally be imitated by the national publisher. It is reasonable to believe that the competitive advantage of Hachette is the knowledge about how to handle and develop the concept in combination with access to the content market.

\section{Conclusions}

A magazine publishing company may, as any company, be viewed as a bundle of resources. According to the resource-based view of the firm, resources that are valuable, rare, imperfectly imitable and for which no strategically equivalent substitute exists can be a source of sustained competitive advantage. Examples of important areas where sustainable competitive advantage can be generated for a magazine publishing company are human resource management, market knowledge and product development. It seems reasonable to believe that it is not resources or assets as such that generate competitive advantage, but the organizational capabilities and routines to handle them. Capabilities, knowledge and routines within human resource management, market research and product development are accumulated over a long time and embedded in the organization and therefore cannot be easily replicated. Also, it can be argued that a characteristic trait of the magazine business is that there is a great deal of causal ambiguity involved, which makes it even harder to imitate the assets or capabilities of a competitor. 
A dominating framework for capturing the value creating logic of a company is the value chain. But decomposing the value creation of a magazine publishing company into discrete and sequential activities raises some problems. An alternative is to view the magazine publishing company as a conductor in a value network, creating value by facilitating exchange between readers, advertisers and the actors on the content market. As a consequence it can be argued that magazine publishing companies are not in the content business but in the relationship business. The possible sources of sustainable competitive advantage are to be found in how the publishing companies manage these relationships.

\section{References}

Amit, R. and Schoemaker, P. (1993) Strategic Assets and Organizational Rent. Strategic Management Journal, Vol. 14.

Barney, J. (1991) Firm Resources and Sustained Competitive Advantage. Journal of Management, 17(1).

Barney, J. (1994) Bringing Managers Back in: A Resource-Based Analysis of the Role of Managers in Creating and Sustaining Competitive Advantages of Firms. In Does Management Matter? - On Competencies and Competitive Advantage. Lund: Lund University, Institute of Economic Research.

Bogaert, I., Martens, R. and van Cauwenbergh A. (1994) Strategy as a Situational Puzzle. In Hamel, G. and Heene, A. (eds) Competence-Based Competition. Chichester: John Wiley \& Sons Ltd.

Brodin, M. and Ekdahl, K. (2000) Den nya vägen till läsaren - en studie av Women's Interest Magazines på Internet. Gothenburg: Gothenburg School of Economics, Department of Marketing, (C-level thesis).

Dierickx, I. and Cool, K. (1989) Asset Stock Accumulation and Sustainability of Competitive Advantage. Management Science, vol 35, No 12, December 1989.

Grant, R. (1991) The Resource-Based Theory of Competitive Advantage: Implications for Strategy Formulation. California Management Review, Spring 1991.

Habann, F. (2000) Management of Core Resources: The Case of Media Enterprises. JMM - the International Journal of Media Management, vol. 2, No 1, 2000.

Hamel, G. and Prahalad, C. K. (1990) The Core Competencies of the Corporation. Harvard Business Review, May-June.

Hofer, C. W. and Schendel, D. (1978) Strategy Formulation: Analytic Concepts. West, St Paul.

Porter, M. (1980) Competitive Strategy: Techniques for Analyzing Industries and Competitors. New York:The Free Press.

Porter, M. (1985) Competitive Advantage: Creating and Sustaining Superior Performance. New York: The Free Press.

Reiner, G. and Ghosh, S. (1988) A New Product Every Week? Lessons from Magazine Publishing. In Stern, C. and Stalk, G. (eds): Perspective on Strategy. New York: John Wiley \& Sons.

Rumelt, R. (1994) "Foreword". In Hamel, G. and Heene, A. (eds) Competence-Based Competition. Chichester: John Wiley \& Sons Ltd.

Stabell, C. and Fjeldstad, Ö. (1998) Configuring Value for Competitive Advantage: On Chains, Hops and Networks. Strategic Management Journal, Vol 19, 1998.

Thompson, J.D. (1967) Organizations in Action. New York: McGraw-Hill.

Verdin and Williamson (1984) Core Competencies, Competitive Advantage and Market Analysis: Forging the Links. In Hamel, G. and Heene, A. (eds) Competence-Based Competition. Chichester: John Wiley \& Sons Ltd.

Wernerfelt, B. (1984) A Resource-Based View of the Firm. Strategic Management Journal, Vol. 5, 1984. 